\title{
Prognostic Significance of Hematological Parameters in Patients with Early-Stage Malignant Melanoma
}

\author{
Huseyin Salih SEMIZ1 ${ }^{1}$, Seher Nazlı KAZAZ ${ }^{2}$, Necla DEMIR ${ }^{3}$, Zeynep Gulsum GUC ${ }^{4}$, \\ Tugba YAVUZSEN ${ }^{5}$, Hulya ELLIDOKUZ ${ }^{5}$, Ilhan OZTOP ${ }^{5}$, Isil SOMALI ${ }^{5}$ \\ ${ }^{1}$ Tepecik Training and Research Hospital, Department of Medical Oncology, Izmir \\ ${ }^{2}$ Karadeniz Technical University, Farabi Hospital, Department of Medical Oncology, Trabzon \\ ${ }^{3}$ Sivas Medicana Hospital, Department of Medical Oncology Sivas \\ ${ }^{4}$ Katip Çelebi University Atatürk Education and Research Hospital, Department Of Medical Oncology, İzmir \\ ${ }^{5}$ Dokuz Eylul University, Institute of Oncology, Department of Clinical Oncology, Izmir, TURKEY
}

\begin{abstract}
The prognosis of melanoma is extremely poor. There are no biomarker that indicate the prognosis. The indirect markers of the antitumoral response such as the neutrophil/lymphocyte ratio (NLR) and platelet/lymphocyte ratio (PLR), derived NLR (dNLR), absolute neutrophil count (ANC), absolute lymphocyte count (ALC) etc. have recently begun to be emphasized. Increased NLR, PLR and dNLR as a consequence of chronic inflammation have been found to be associated with poor prognosis in many cancers. The aim of this study is explore the role of this parameters in patients with early-stage melanoma. We retrospectively evaluated 120 patients admitted to our clinic with stage I-III melanoma with ANC, ALC, absolute platelet count(APC), as well as NLR, dNLR, and PLR values at the time of diagnosis, relaps and metastasis and evaluate their impact on prognosis. Patients with active infection, receiving steroids, with a chronic inflammatory disease that may alter the hematological parameters, and those with another malignancy other than melanoma were excluded. The median follow-up was 52 months. OS and DFS were significantly worse in patients with an NLR above 2.84 . Also, in patients with a dNLR value above 1.96 ( $p=0.007)$. The were no relationship between PLR value, OS and DFS, and between gender and OS. OS was significantly lower in patients over 65 years of age $(p<0.001)$. These results suggested that haematological parameters can be used to estimate the prognosis of melanoma. These results suggested that haematological parameters can be used to estimate the prognosis of melanoma.
\end{abstract}

Keywords: Melanoma, Adjuvant, Inflammation, Neuthrophil, Lymphocyte

\section{ÖZET}

\section{Erken Evre Malign Melanom Hastalarında Hematolojik Parametrelerin Prognostik Önemi}

Melanom oldukça kötü prognozlu bir malignitedir, fakat prognozu belirleyebilecek bir biyobelirteç yoktur. Nötrofil / lenfosit oranı (NLR) ve trombosit / lenfosit oranı (PLR), türetilmiş NLR (dNLR), mutlak nötrofil sayısı (ANC), mutlak lenfosit sayıSı (ALC) gibi antitümoral yanııı dolaylı belirteçleri yakın zamanda araştııımaya başlanmıştır. Kronik inflamasyonun bir sonucu olarak artan NLR, PLR ve dNLR'nin birçok kanserde kötü prognoz ile ilişkili olduğu bulunmuştur. Bu çalışmanın amacı, erken evre melanomalı hastalarda bu parametrelerin rolünü araştırmaktır. Kliniğimize evre I-III melanoma tanısıyla başvuran 120 hastayı ANC, ALC, mutlak trombosit sayımı (APC) ve ayrıca NLR, dNLR ve PLR değerleri ile tanı, relaps ve metastaz sırasında yapılan ölçümler ve bu ölçümlerin sağ kalım üzerine etkilerini değerlendirdik. Hematolojik parametreleri değiştirebilecek kronik enflamatuar bir hastalığı olan, steroid alan, aktif enfeksiyonu olan hastalar ve melanom dışında başka bir malignitesi olan hastalar çalışma dışı bırakıldı. Ortalama takip süresi 52 aydı. OS ve DFS, NLR'nin 2.84 üzerinde olduğu hastalarda ve dNLR değeri 1,96'nın üzerinde olan hastalarda ( $p=0.007$ ) anlamlı olarak daha kötüydü. PLR değeri, OS ve DFS ile cinsiyet ve OS arasında ilişki yoktu. OS, 65 yaş üstü hastalarda anlamlı derecede daha kötüydü ( $p<0.001)$. Bu sonuçlar, hematolojik parametrelerin, melanomun prognozunu tahmin etmek için kullanılabileceğini göstermiştir.

Anahtar Kelimeler: Melanom, Adjuvan, İnflamasyon, Nötrofil, Lenfosit 


\section{INTRODUCTION}

Malignant melanoma causes the highest number of deaths among skin cancers. Its prevalence has recently increased to a significant extent. 5-year overall survival is $97 \%$ in patients with stage 1 malignant melanoma, while stage 4 (M1c) patients have a 1 -year survival of $33 \% .^{1}$

As the prognosis is largely poor, there are studies being conducted on a variety of parameters to indicate the course of disease. Among them, several prognostic factors such as anatomic localization of the tumor, Breslow thickness, depth of tumor invasion, lymph node involvement, tumor ulceration, mitotic activity, and lymphovascular invasion have been investigated. ${ }^{2,3,4}$ In addition, indirect markers of the immune system's anti-tumoral response such as the neutrophil/lymphocyte ratio (NLR) and platelet/lymphocyte ratio (PLR), derived NLR (dNLR) calculated by the neutrophil/(leukocytelymphocyte) formula, absolute neutrophil count, absolute lymphocyte count, CRP (C-reactive protein), serum amyloid A (SAA) have recently begun to be emphasized. ${ }^{5}$ Increased NLR, PLR and dNLR as a consequence of chronic inflammation have been found to be associated with poor prognosis in many cancers. ${ }^{6}$ There are available studies suggesting that chronic inflammation is effective in the development and spread of many malignancies. Therefore, this issue has been elaborated by many researchers. ${ }^{6,7,8}$ Increased NLR as a consequence of chronic inflammation has been associated with poor prognosis in many cancers including the breast, pancreatic, rectum, colorectal and lung cancers. ${ }^{6}$ However, the role of this ratio in predicting prognosis in patients with malignant melanoma remains a potential research topic. Almost all studies investigating the prognostic significance of NLR, PLR and dNLR in malignant melanoma have been conducted on patients with metastatic disease. ${ }^{9,10}$ In this study, we aimed to examine the role of hematologic parameters that change as secondary to inflammation, especially NLR, in predicting prognosis of patients with early-stage malignant melanoma due to a lack of detailed studies on the importance of those parameters in patients with early-stage melanoma.

\section{PATIENTS AND METHODS}

In this study, we retrospectively evaluated the data of a total of 120 patients over 18 years of age who referred to our clinic with the diagnosis of stage I-III malignant melanoma between 2000 and 2014 after the approval of the Dokuz Eylül University Noninvasiv Research Ethics Board, date 16 September 2019, aproval number 2019/23-37.

Patient data were collected retrospectively from the online database system of the hospital. We recorded absolute neutrophil count, absolute lymphocyte count, absolute platelet count, as well as NLR, dNLR, and PLR values at the time of diagnosis (before curative surgery). The NLR was calculated by dividing the absolute neutrophil count by the absolute lymphocyte count and PLR was calculated by dividing the absolute platelet count by the absolute lymphocyte count. In addition, dNLR was calculated by the formula of absolute neutrophil count/ (absolute leukocyte count - absolute lymphocyte count). We recorded the value of each parameter at the time of local or systemic recurrence as NLR2, dNLR2, and PLR2, and examined their effects on overall survival (OS) and diseasefree survival (DFS). Also, the recalculated values at relapse/metastasis were compared with the values at the time of diagnosis. Baseline absolute neutrophil count, absolute lymphocyte count, absolute platelet count, NLR, dNLR, and PLR were recorded from the laboratory data studied one week prior to the operation. NLR2, dNLR2 and PLR2 values were based on the laboratory data (within one month) available when relapse was detected. Due to the insufficient number of patients, no ROC curve could be generated to determine cut-offs for each of these parameters. For this reason, we accepted mean NLR, dNLR and PLR values as a cutoff for those parameters. Patients were divided into two groups with cut-off values above and below the cut-off value and the groups were examined with respect to age, sex, tumor location, lymph node involvement and presence of ulceration in the tumor. While their relationship with age was being evaluated, patients were examined in two groups, namely those younger and older than 65 years of age. Tumor location was grouped as head-neck, upper extremity, lower extremity, trunk and others. Patients with active infection, receiving steroids, 
with a chronic inflammatory disease that may alter the hematological parameters at the time when the laboratory data were recorded, and those with another malignancy other than melanoma were excluded from the study.

The data were evaluated using the SPSS 15.0 package program. Chi-square test was used in the analysis of the variables indicated by counts. While analyzing the variables indicated by measurements, the groups were compared relying on the T-test and Mann-Whitney U-test according to their compliance with normal distribution. We used KaplanMeier Test for life analysis. The Cox Regression Model was generated for the multiple analysis. The threshold of significance was set at $\mathrm{p}<0.05$.

\section{RESULTS}

Of the 120 patients, $61(50.8 \%)$ were female and 59 $(49.2 \%)$ were male. The median age was 52 years. At the time of diagnosis, $19.3 \%$ of the patients were stage I, $31.9 \%$ were stage II, and $48.7 \%$ were stage III. Tumor loci included trunk, lower extremity, head and neck, and upper extremity in the order of frequence. 38 patients (36.9\%) presented lymph node involvement at the time of diagnosis.

$55.8 \%$ of the patients were administered adjuvant interferon therapy (IFN). 38 (31.7\%) patients developed subsequent local recurrence or distant organ recurrence. The median follow-up was 52 months. 77 patients $(64.2 \%)$ were alive during the data analyses. Median OS was 52,45 months and DFS was 41,72 months. Disease characteristics and sociodemographic data are shown in Table 1. Mean cutoff values were 2.84 for NLR, 145.6 for PLR, and 1.96 for dNLR, respectively. Although NLR, dNLR and PLR values increased numerically in patients with recurrence, this increase did not reach statistical significance (Table 2).

\begin{tabular}{|c|c|c|}
\hline Characteristic & Number (n) & $\%$ \\
\hline \multirow[t]{2}{*}{ Age } & \multicolumn{2}{|l|}{ Mean (min-max) } \\
\hline & \multicolumn{2}{|l|}{$52.07(22-91)$} \\
\hline \multicolumn{3}{|l|}{ Gender } \\
\hline Male & 59 & 49.2 \\
\hline Female & 61 & 50.8 \\
\hline \multicolumn{3}{|l|}{ Stage } \\
\hline Stage 1 & 23 & 19.3 \\
\hline Stage 2 & 38 & 31.9 \\
\hline Stage 3 & 58 & 48.7 \\
\hline \multicolumn{3}{|l|}{ Tumor location } \\
\hline Head and neck & 28 & 23.5 \\
\hline Upper extremity & 16 & 13.4 \\
\hline Lower extremity & 29 & 24.4 \\
\hline Torso & 31 & 26.1 \\
\hline Other & 15 & 12.6 \\
\hline \multicolumn{3}{|l|}{ Ulceration } \\
\hline Yes & 45 & 37.5 \\
\hline No & 45 & 37.5 \\
\hline Unstated & 30 & 25 \\
\hline \multicolumn{3}{|l|}{ Breslow } \\
\hline$\leq 1 \mathrm{~mm}$ & 15 & 13.6 \\
\hline $1.01-2 \mathrm{~mm}$ & 16 & 14.5 \\
\hline 2.01-4 mm & 38 & 34.5 \\
\hline$>4 \mathrm{~mm}$ & 41 & 37.3 \\
\hline \multicolumn{3}{|c|}{ Lymph node involvement } \\
\hline Yes & 38 & 31.7 \\
\hline No & 65 & 54.2 \\
\hline Unknown & 17 & 14.2 \\
\hline \multicolumn{3}{|c|}{ Distant or local recurrence } \\
\hline Yes & 38 & 31.7 \\
\hline No & 82 & 68.3 \\
\hline \multicolumn{3}{|c|}{ Adjuvant systemic treatment } \\
\hline Interferon & 67 & 55.8 \\
\hline Other & 16 & 13.3 \\
\hline No & 37 & 30.8 \\
\hline
\end{tabular}

\begin{tabular}{|llllll|}
\hline Table 2. NLR, PLR and dNLR distribution & \multicolumn{1}{l|}{} \\
\hline & PLR & NLR & PLR2 & NLR2 & dNLR \\
\hline Number $(n)$ & 120 & 120 & 33 & 33 & 120 \\
Mean & 145.60 & 2.84 & 168.19 & 4.47 & 1.96 \\
Median & 125.30 & 2.10 & 127.00 & 2.39 & 1.59 \\
Standard Deviation & 105.10 & 4.07 & 92.33 & 6.87 & 2.06 \\
Minimum & 19.80 & .56 & 65.77 & .79 & .50 \\
Maximum & 955.00 & 44.50 & 438.00 & 39.25 & 22.25 \\
\hline
\end{tabular}

UHOD Number: 2 volume: 30 Year: 2020 
International Journal of Hematology and Oncology

\begin{tabular}{|c|c|c|c|c|c|}
\hline & Age & Number (n) & Mean & Standard Deviation & $\mathbf{p}$ \\
\hline \multirow[t]{2}{*}{ NLR } & $<65$ & 94 & 2.39 & 1.40 & 0.015 \\
\hline & $\geq 65$ & 26 & 4.44 & 8.26 & \\
\hline \multirow[t]{2}{*}{ PLR } & $<65$ & 94 & 135.44 & 71.18 & 0.241 \\
\hline & $\geq 65$ & 26 & 182.45 & 178.59 & \\
\hline \multirow[t]{2}{*}{$\mathrm{dNLR}$} & $<65$ & 94 & 1.75 & 0.89 & 0.033 \\
\hline & $\geq 65$ & 26 & 2.73 & 4.05 & \\
\hline
\end{tabular}

NLR and dNLR levels were higher in patients older than 65 years of age $(p=0.015$ and $p=0.033$, respectively). Although it remained below the threshold of significance, the PLR value was numerically higher in patients 65 years of age or older in comparison to younger patients (Table 3). Both NLR and dNLR and PLR were significantly higher in patients with head-neck and lower extremity tu- mors than patients with upper extremity and trunklocalized tumors (Table 4). NLR and PLR levels were not significantly correlated with known risk factors such as sex, lymph node involvement, presence of ulceration in the tumor, etc. Likewise, we have found that dNLR is independent of factors such as sex, lymph node involvement, and tumor ulceration.

\begin{tabular}{|c|c|c|c|c|}
\hline Tumor Location & & NLR & PLR & dNLR \\
\hline \multirow[t]{2}{*}{ Upper extremity } & Mean & 2.68 & 126.19 & 1.91 \\
\hline & Standard Deviation & 1.99 & 51.81 & 1.26 \\
\hline \multirow[t]{2}{*}{ Lower extremity } & Mean & 4.12 & 197.17 & 2.57 \\
\hline & Standard Deviation & 7.87 & 173.39 & 1.72 \\
\hline \multirow[t]{2}{*}{ Torso } & Mean & 1.98 & 109.73 & 1.51 \\
\hline & Standard Deviation & .90 & 38.69 & 1.41 \\
\hline \multirow[t]{2}{*}{ Head and neck } & Mean & 2.85 & 158.09 & 2.02 \\
\hline & Standard Deviation & 1.50 & 88.45 & 1.83 \\
\hline \multirow[t]{2}{*}{ Other } & Mean & 2.22 & 116.72 & 1.65 \\
\hline & Standard Deviation & 1.00 & 50.13 & 1.67 \\
\hline$p$ value & & 0.038 & 0.015 & 0.069 \\
\hline
\end{tabular}

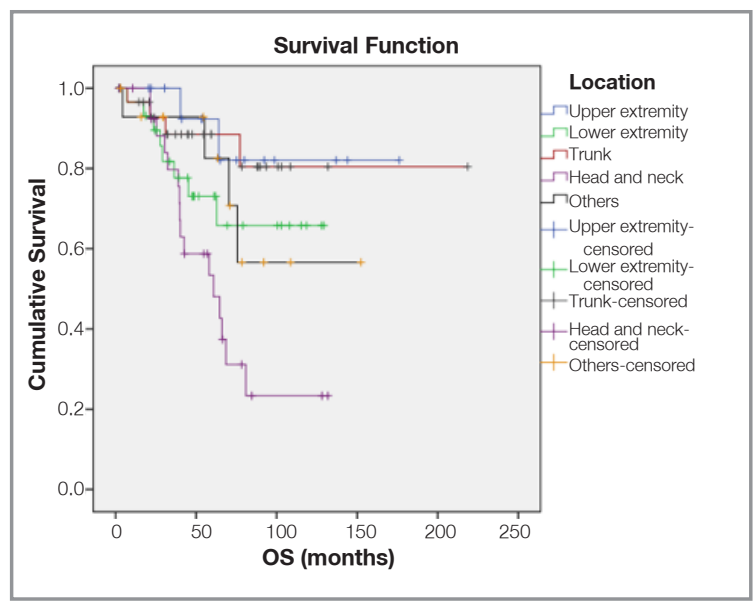

Figure 1. Relationship between tumor location and OS

An evaluation of the results in terms of survival showed that head-neck and lower extremity tumors presented a longer OS than those localized in the trunk and upper extremity (Figure 1). OS and DFS were significantly worse in patients with an NLR above 2.84 (Figure 2 and 3). Also, in patients with a dNLR value of 1.96 or less, OS was significantly longer than those above this value $(\mathrm{p}=0.007)$. Similarly, DFS was better in the group with dNLR levels of 1.96 or less, yet the results did not reach statistical significance $(\mathrm{p}=0.094)$ (Figure 4 and 5). We detected no relationship between PLR level and OS and DFS, and between sex and OS. OS was significantly lower in patients over 65 years of age $(\mathrm{p}<0.001)$. 


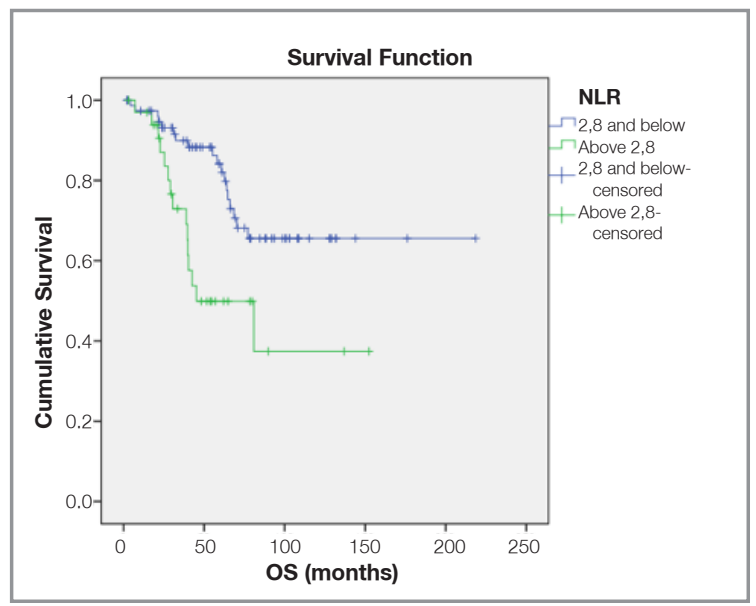

Figure 2. Relationship between NLR and OS

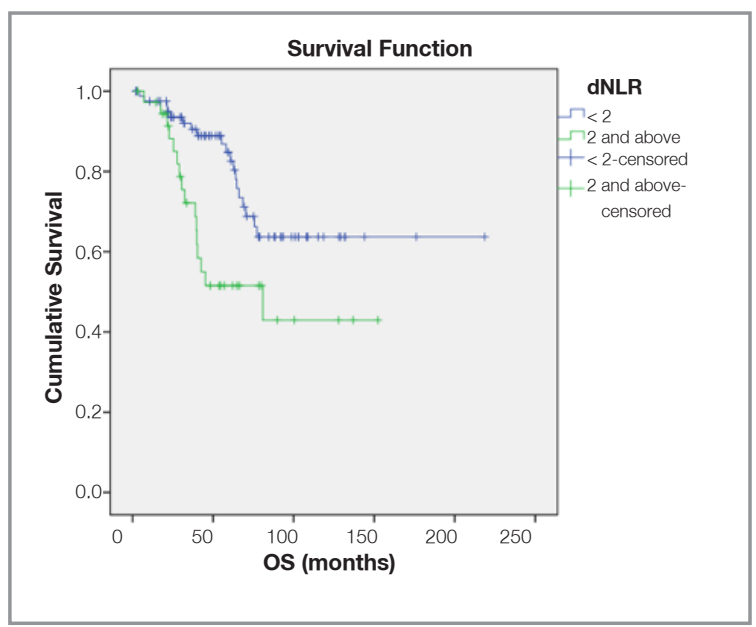

Figure 4. Relationship between dNLR and OS

In the Cox regression model generated including the tumor locus, age, NLR, dNLR and PLR, malignant melanoma-associated death risk was found to be 4.9 times higher in patients over 65 years of age compared with those under 65 years of age.

\section{DISCUSSION}

In this study we observed that some of hematologic parameters, location of primary tumor and age are associated with the survival of patients with early stage melanoma. The prognostic and predictive importance of NLR, dNLR, PLR, lymphocyte and neutrophil counts have been a subject of investigation, especially in patients with metastatic malignant melanoma who are receiving anti-PD-1

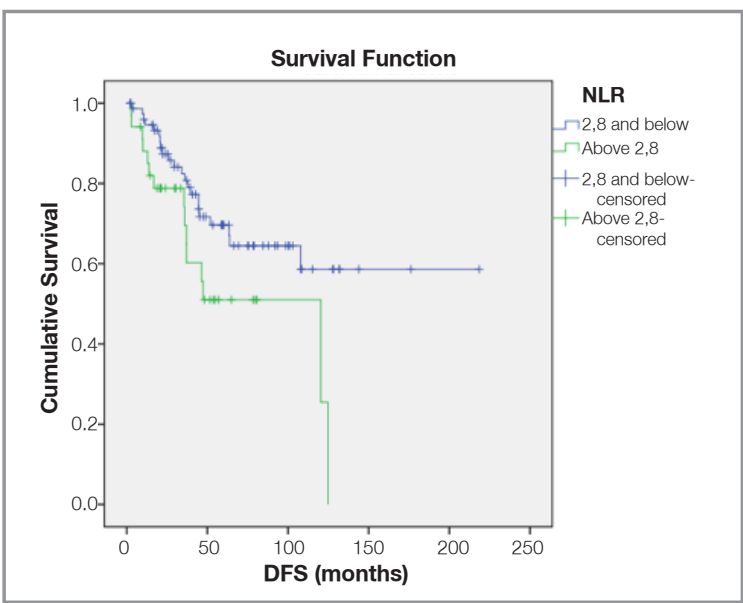

Figure 3. Relationship between NLR and DFS

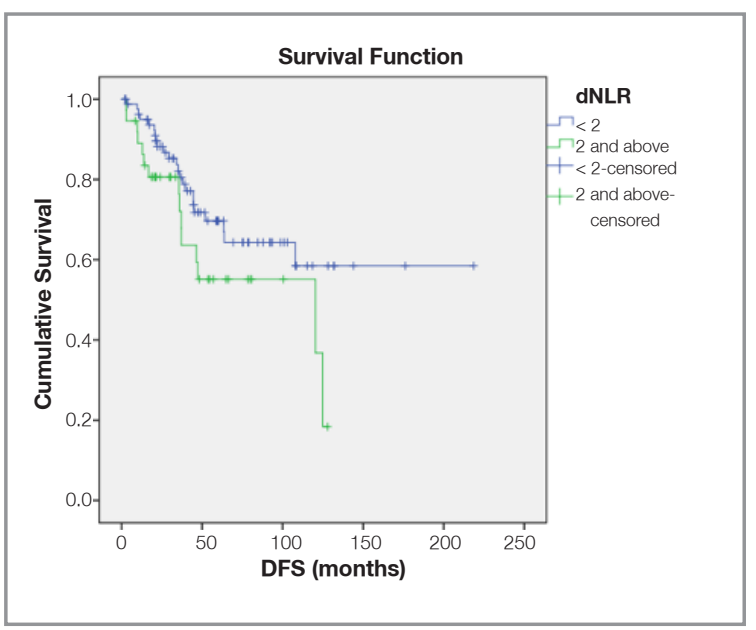

Figure 5. Relationship between dNLR and DFS

treatment such as ipilimumab and pembrolizumab. But different cutoff values have been used for NLR and other hematologic parameters in the literature. Identifying different cutoffs for each cohort seems to be the right approach. We used mean values ( 2.84 for NLR, 145.6 for PLR and 1.96 for dNLR) as cutoffs in this study. As part of this study, we found that having NLR above 2.84 negatively affected both OS and DFS. Like our study, Zaragoza et al. found that a pre-ipilimumab NLR level over 4 was associated with poor OS in cases of stage IV malignant melanoma. ${ }^{11}$ Di Giacomo et al. set the NLR cutoff value at 2.81 prior to treatment. ${ }^{12}$

Similar to the NLR level, dNLR levels have been tested in the context of survival. In a study in which Proctor et al. compiled data on many cancers ex- 
cept melanoma, they showed that dNLR and NLR levels had similar prognostic value, especially in patients with advanced-stage colorectal cancer. In this study, cutoff values of 5 and 2 were taken for NLR and dNLR, respectively, and the values above the cutoff point correlated with negative survival. ${ }^{7}$ Nevertheless, there is no study on the prognostic significance of dNLR in patients with early-stage malignant melanoma. In the present study, we found longer OS values in patients with dNLR levels equal to or lower than 1.96 in comparison to those above. Likewise, DFS was longer in the patient group with a dNLR of 1.96 or less; however, it did not reach the level of significance. Although the level of dNLR was higher in cases over 65 years of age, it did not reach statistical significance.

A review of the relevant literature shows that almost all studies attempting to determine the relationship between inflammatory markers and survival have been conducted on patients with metastatic-stage melanoma. ${ }^{13}$ There is no study examining NLR and dNLR in relation to OS and PFS in stage I-III melanoma cases, and studies on metastatic patients have rather focused on the predictive value of these parameters. ${ }^{14}$ We primarily aimed to determine the prognostic significance of these parameters. In this respect, our study represents a first. It is also important to note another finding of our study is being over 65 years of age was an independent risk factor for survival.

There are also several limitations to this study. For example, the young patient population (age: $52 \pm 15$ ) may have positively affected the outcome. However, some results may have turned out to be insignificant as the AJCC published the latest melanoma classification in 2010 and some patient's data were missing. Another limitation of this study is its retrospective nature. We excluded patients with in an inflamatory condition but it is difficult to evaluate this parameter in a retrospective trial.

In conclusion, although predicting an immunologic tumor such as melanoma by simple hematologic parameters is a promising development, this method has not yet been routinely employed despite numerous studies with positive results in this context, which is due to the fact that these parameters still lack a standard value. Our results the on prognos- tic significance of NLR and dNLR values obtained in patients with early stage melanoma suggest that these parameters can also be used to estimate early-stage disease prognosis. Although our findings on the prognostic significance of NLR and dNLR values in the early-stage malignant melanoma patients are consistent with the results obtained in other studies conducted on metastatic patients, we have determined that markers such as absolute neutrophil count, absolute lymphocyte count, and PLR have no role in estimating prognosis in the early stage. Further prospective studies are required on these prognostic markers, which may contribute to the decision of adjuvant therapy.

\section{REFERENCES:}

1. Siegel RL, Miller KD, Jemal A. Cancer statistics, 2015. CA Cancer J Clin 65: 5-29, 2015.

2. Green AC, Baade P, Coory M, et al. Population-based 20year survival among people diagnosed with thin melanomas in Queensland, Australia. J Clin Oncol 30: 1462-1467, 2012.

3. Maurichi A, Miceli R, Camerini T, et al. Prediction of survival in patients with thin melanoma: results from a multi-institution study. J Clin Oncol 32: 2479-2485, 2014.

4. Balch CM, Soong SJ, Gershenwald JE, et al. Prognostic factors analysis of 17,600 melanoma patients: validation of the American Joint Committee on Cancer melanoma staging system. J Clin Oncol 19: 3622-3634, 2001.

5. Schmidt H, Bastholt L, Geertsen P, et al. Elevated neutrophil and monocyte counts in peripheral blood are associated with poor survival in patients with metastatic melanoma: a prognostic model. Br J Cancer 93: 273-278, 2005.

6. Margolis KL, Rodabough RJ, Thomson CA, et al. Prospective study of leukocyte count as a predictor of incident breast, colorectal, endometrial, and lung cancer and mortality in postmenopausal women. Arch Intern Med 167: 1837-1844, 2007.

7. Proctor MJ, McMillan DC, Morrison DS, et al. A derived neutrophil to lymphocyte ratio predicts survival in patients with cancer. Br J Cancer 107: 695-699, 2012.

8. Mantovani A, Allavena P, Sica A, Balkwill F. Cancer related inflammation. Nature 454: 436-444. 2008.

9. Schmidt H, Suciu S, Punt CJ, et al. American Joint Committee on Cancer Stage IV Melanoma; EORTC 18951. Pretreatment levels of peripheral neutrophils and leukocytes as independent predictors of overall survival in patients with American Joint Committee on Cancer Stage IV Melanoma: results of the EORTC 18951 Biochemotherapy Trial. J Clin Oncol 25: 1562-1569, 2007. 
10. Baykan H, Cihan YB, Ozyurt K. Roles of white blood cells and subtypes as inflammatory markers in skin cancer. Asian Pac J Cancer Prev 16: 2303-2306, 2015.

11. Zaragoza J, Caille A, Beneton N, et al. High neutrophil to lymphocyte ratio measured before starting ipilimumab treatment is associated with reduced overall survival in patients with melanoma. Br J Dermatol 174: 146-151, 2016.

12. Di Giacomo AM, Calabrò L, Danielli R, et al. Long-term survival and immunological parameters in metastatic melanoma patients who responded to ipilimumab $10 \mathrm{mg} / \mathrm{kg}$ within an expanded access programme. Cancer Immunol Immunother 62: 1021-1028, 2013.

13. Ferrucci PF, Gandini S, Battaglia A, et al. Baseline neutrophilto-lymphocyte ratio is associated with outcome of ipilimumab-treated metastatic melanoma patients. Br J Cancer 112: 1904-1910, 2015.

14. Weide B, Martens A, Hassel JC, et al. Baseline biomarkers for outcome of melanoma patients treated with pembrolizumab. Clin Cancer Res 22: 5487-5496, 2016.

\section{Correspondence:}

Dr. Huseyin Salih SEMIZ

Kazim Dirik Mahallesi, Sanayi Caddesi

No: 7

Bornova, IZMIR / TURKEY

Tel: (+90-533) 7182006

e-mail: hsalihsemiz@hotmail.com

\section{ORCIDs:}

Huseyin Salih Semiz:

0000-0002-7083-8517

Seher Nazli Kazaz:

0000-0002-8181-000X

Necla Demir:

$0000-0003-1051-4032$

Zeynep Gülsüm Güc:

0000-0001-8960-2208

Tugba Yavuzsen:

0000-0001-9375-8133

Hulya Ellidokuz

0000-0001-8503-061X

Ilhan Oztop:

0000-0002-0425-0651

Isil Somali

0000-0003-3135-9043 